\title{
PERANCANGAN WEB SEBAGAI MEDIA PROMOSI DAN EDUKASI PRODUK IKAN TERI (TERICHIP)
}

\author{
Ahmad Tsaqib Habibul Mujib ${ }^{1)}$, Paulus Tofan Rapiyanta ${ }^{2)}$ \\ Universitas Bina Sarana Informatika Kampus Kota Yogyakarta \\ Syaqieb003@gmail.com, tofanpaulus@gmail.com
}

\begin{abstract}
Terichip is a food product that made from anchovy which is rich in calcium. Terichip sales have been using conventional methods so that it's need to be helped to expand. Besides that, people needs to be educated on the importance of adequate calcium intake. The average consumption of the Indonesian people is still relatively low, which is $254 \mathrm{mg} /$ day. For pregnant and lactating women, calcium intake of less than $600 \mathrm{mg} /$ day can endanger the health of the mother and baby. Authors try to solve this problems uses the waterfall method to develop system based on website, which starts from needs analysis, design, coding, and testing. Main function of this web is as a medium of promotion and education. Besides that, user also can join in social program for help poor people by giving donation. With this website-based system, terichip product sales can be expand, the people can get education on the importance of adequate calcium intake, also can make to provide real help, specially for poor pregnant and lactating women
\end{abstract}

Keywords : Terichip, Calcium, anchovy, website

ABSTRAK - Terichip adalah sebuah produk makanan berbahan dasar ikan teri yang kaya akan kalsium. Penjualan Terichip selama ini masih menggunakan cara konvensial sehingga perlu dibantu untuk mengekspansi penjualannya. Di sisi lain, masyarakat perlu diedukasi akan pentingnya asupan kalsium yang cukup. Konsumsi rata-rata masyarakat Indnesia masih tergolong rendah, yaitu $254 \mathrm{mg} / \mathrm{hari}$. Bagi ibu hamil dan menyusui, asupan kalsium yang kurang dari $600 \mathrm{mg} / \mathrm{hari}$ dapat membahayakan kesehatan ibu dan bayi. Untuk mengatasi permasalahan ini, penulis menggunakan metode waterfall untuk mengembangkan sistem berbasis website yang dimulai dengan tahapan analisa kebutuhan, desain, pengkodean, dan testing. Fungsi utama dari web ini adalah sebagai media promosi dan edukasi. Selain itu, pengguna juga dapat turut serta dalam program sosial bagi masyarakat yang kurang mampu dengan memberikan donasi. Dengan sistem berbasis website ini penjualan produk terichip dapat ditingkatkan, masyarakat dapat diberikan edukasi akan pentingnya asupan kalsium yang cukup, serta dapat membantu memberikan bantuan secara nyata khususnya bagi ibu hamil dan menyusui yang kurang mampu.

Kata kunci: Terichip, Kalsium, Teri, Website

\section{Pendahuluan}

Asupan Kalsium penting bagi ibu hamil dan menyusui. Asupan kalsium yang cukup dapat mengurangi kejadian hipertensi selama kehamilan. Penelitian saccoet al. di Peru menunjukkan bahwa prevelensi ibu hamil memiliki asupan kalsium sebesar $86 \%$ (Purnasari dkk., 2016a).

Konsumsi kalsium rata-rata masyarakat Indonesia termasuk rendah. Hal ini merupakan ancaman dan masalah kesehatan yang serius bagi masyarakat Indonesia khususnya ibu hamil dan menyusui. Asupan kalsium yang rendah (<600mg/hari) akan membahayakan kesehatan ibu dan janin karena akan meningkatkan resiko hipertensi, preeklampsia dan kelahiran prematur. Oleh sebab itu, masyarakat perlu mendapatkan edukasi yang cukup tentang kebutuhan akan kalsium.

Terichip merupakan produk makanan berbahan dasar ikan teri dengan kandungan gizi cukup tinggi. Terichip dapat menjadi salah satu solusi bagi ibu hamil dan menyusui dalam mengatasi kekurangan kalsium sehingga dapat mencegah terjadinya Hipertensi Dalam Kehamilan (HDK), preeklamsia dan kelahiran prematur. Penjualan Terichip selama ini masih dinilai kurang efektif karena pemasaran masih dilakukan secara offline sehingga jangkauan pasarnya masih terbatas. Maka dari itu diperlukan media informasi yang mudah diakses dan mampu menjangkau seluruh wilayah di Indonesia. Maka diperlukan solusi untuk permasalahan tersebut berupa Perancangan Web sebagai media promosi dan edukasi produk ikan teri (Terichip).

Tujuan dari penelitian ini adalah membuat sistem informasi berbasis website yang dapat digunakan sebagai media promosi produk terichip dan media edukasi tentang pentingnya asupan kalsium. Manfaat yang diharapkan adalah meningkatnya penjualan produk terichip dan kesadaran masyarakat akan pentingnya asupan kalsium, khususnya bagi ibu hamil dan menyusui. 


\section{Tinjauan Pustaka}

\section{Terichip}

Terichip merupakan produk makanan berbahan dasar ikan teri dengan kandungan gizi cukup tinggi. Terichip memiliki kandungan kalsium sebesar 972 mg per 100 g. Tidak hanya kaya kalsium, ikan teri juga memiliki kandungan protein yang tinggi yaitu $10.3 \mathrm{~g}$ per $100 \mathrm{~g}$.

Tabel 1. Komposisi Kimia Ikan Teri (Per $100 \mathrm{~g} \mathrm{BDD})$

\begin{tabular}{|c|c|c|}
\hline No. & Kandungan Gizi & Jumlah \\
\hline 1. & Energi & $74 \mathrm{kkal}$ \\
\hline 2. & Karbohidrat & $4.1 \mathrm{~g}$ \\
\hline 3. & Lemak & $1.4 \mathrm{~g}$ \\
\hline 4. & Protein & $10.3 \mathrm{~g}$ \\
\hline 5. & Kalsium & $972 \mathrm{mg}$ \\
\hline
\end{tabular}

Sumber : (Nugrahani, 2014)

Menurut data dari Depkes RI, tahun 2008 (Purnasari, 2016b), konsumsi kalsium rata-rata masyarakat Indonesia termasuk rendah, yaitu hanya sebesar $254 \mathrm{mg} / \mathrm{hari}$ untuk orang dewasa. Sedangkan, rekomendasi asupan kalsium oleh Food \& Nutrition Board yakni sebanyak $1000 \mathrm{mg} / \mathrm{hari}$ untuk orang dewasa pada rentang usia 19-50 tahun termasuk ibu hamil dan menyusui.

Terichip menjadi salah satu solusi untuk meningkatkan asupan kalsium, khususnya bagi ibu hamil dan menyusui karena memiliki kandungan kalsium yang mendekati rekomendasi asupan kalsium harian.

\section{Website}

Website adalah kumpulan halaman yang menampilkan informasi statis maupun dinamis dan saling terhubung dengan jaringan (Istiono, dkk, 2016)

\section{Basis data}

Menurut Fatansyah dalam (Supriyanta dan Nussy, 2016), Basis berarti markas atau tempat berkumpul. Sedangkan data adalah representasi fakta dunia nyata yang mewakili suatu objek.

\section{Struktur Navigasi}

Menurut Syukriah dalam (Pribadi, 2016) "Struktur navigasi merupakan alur dari suatu program yang dapat membantu mengorganisasikan seluruh elemen yang terhubung dalam perancangan".

\section{Entity Relationship Diagram (ERD)}

Menurut Sukamto dalam (Supriyanta, dan Nussy, 2016) "Entity Relationship Diagram adalah tahap awal perancangan basis data reasional dimana dibuat bentuk hubungan antar entitas".

\section{Logical Record Structure (LRS)}

Menurut Friyadie dalam (Supriyanta, dan Nussy 2016) "Logical Record Structure (LRS) adalah hasil pemodelan Entity Relationship (ER) beserta atributnya".

\section{Software Development Life Cycle (SDLC)}

Menurut Sukamto dalam (Destiana, 2014) SDLC adalah proses mengembangkan suatu sistem perangkat lunak dengan menggunakan model dan metodologi tertentu.

Metode pengembangan perangkat lunak yang digunakan dalam penelitian ini adalah model air terjun (waterfall). Tahap-tahap dalam model waterfall adalah sebagai berikut;

a. Analisis Kebutuhan Perangkat Lunak

Pada proses ini informasi tentang kebutuhan sistem dikumpulkan secara intensif. Tujuannya adalah untuk menspesifikasikan kebutuhan perangkat lunak agar dapat memenuhi kebutuhan user. Spesifikasi kebutuhan perangkat lunak pada tahap ini perlu untuk didokumentasikan.

b. Desain

Desain perangkat lunak adalah proses yang fokus pada desain pembuatan program termasuk struktur data, arsitekstur perangkat lunak, representasi antarmuka, dan prosedur pengkodean. Tahap ini mentranslasi kebutuhan ke representasi desain agar dapat diwujudkan menjadi program pada tahap selanjutnya. Desain perangkat lunak yang dihasilkan pada tahap ini juga perlu didokumentasikan.

c. Pembuatan Kode Program

Desain harus ditranslasikan ke dalam program perangkat lunak. Hasil dari tahap ini adalah program komputer sesuai dengan desain yang telah dibuat pada tahap sebelumnya.

\section{d. Pengujian (Testing)}

Pengujian fokus pada perangkat lunak secara logika dan fungsional untuk memastikan bahwa semua bagian sudah diuji. Hal ini dilakukan untuk meminimalisir kesalahan (error) dan memastikan keluaran yang dihasilkan sesuai dengan yang diinginkan.

\section{Metode Penelitian}

Menjelaskanmetodepenetian yang digunakansertalangkah-langkahpenelitian. Jenispenelitian, pendekatanpenelitiandaninstrumenpenelitian.

Metode pengembangan perangkat lunak yang digunakan dalam penelitian ini adalah SDLC model Air terjun (waterfall). Tahapan pengembangan perangkat lunak yang dilakukan adalah sebagai berikut;

\section{Analisis Kebutuhan}

Analisis Kebutuhan yang dilakukan dalam penelitian mencakup kebutuhan 
pengguna dan kebutuhan sistem, baik yang sifatnya fungsional maupun non-fungsional. Kebutuhan pengguna mencakup kebutuhan pengunjung, donator dan Admin. Sedangkan kebutuhan sistem mencakup kebutuhan operasional dan keamanan..

Berdasarkan pengumpulan data yang telah dilakukan melalui observasi dan wawancara, didapatkan informasi tentang kebutuhan pengguna sebagai berikut;

a. Pengguna hanya dapat melihat halaman pada menu-menu yang tersedia dalam website ini dan dapat melakukan pendaftaran sebagai donator.

b. Donatur dapat melihat semua halaman, masuk (login) ke halaman Donatur dan melakukan pemberian donasi serta melihat laporan donasi. Selain itu, donator juga dapat mengelola data profil donator.

c. Admin dapat masuk (Login) ke halaman admin dan mengelola keseluruhan halaman dan menu yang tersedia dalam website ini.

Selain kebutuhan pengguna, analisis kebutuhan sistem juga dilakukan yang mencakup kebutuhan operasional dan keamanan. Kebutuhan operasional sistem dalam penelitian ini berpedoman pada spesifikasi sistem yang digunakan untuk menjalankan program. 3 komponen utama yang menjadi kebutuhan sistem adalah Sistem Operasi, Prosesor dan Memori Komputer. Pada penelitian ini, sistem operasi yang digunakan adalah windows 10 Pro 64-Bit dengan Prosesor Intel Core i5 $7^{\text {th }}$ Gen dan memori RAM $4096 \mathrm{MB}$.

Sedangkan untuk analisis kebutuhan keamanan yang diperlukan adalah penerapan password bagi pengguna, baik sebagai Admin maupun Donatur. Kedua pengguna ini memiliki akses lebih jika dibandingkan dengan pengguna umum.

\section{Desain Perangkat Lunak}

Desain perangkat lunak meliputi desain antarmuka, basis data, dan struktur navigasi. Desain antarmuka secara umum dibuat dalam tiga model, yaitu untuk pengguna umum (user), donatur dan Admin.

Pengguna umum (user) hanya dapat melihat halaman tanpa bisa mengubah informasi apapun, sehingga desain antarmuka yang dibuat juga hanya bersifat informatif. Desain antarmuka pengguna umum ditunjukkan pada gambar 1 .

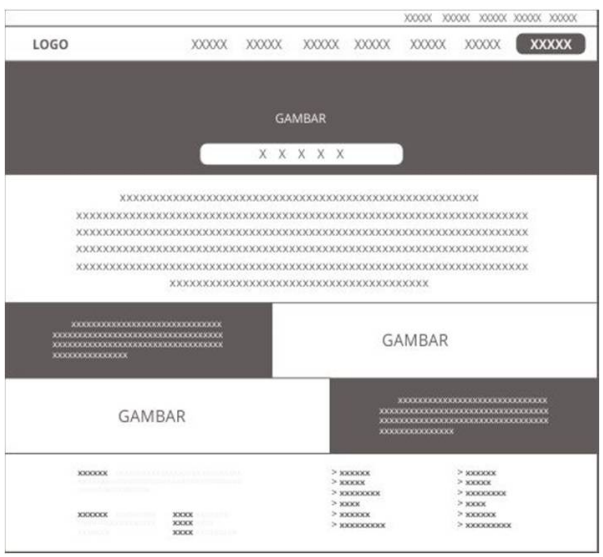

Gambar 1. Desain antarmuka pengguna

Pada sisi kiri atas halaman pengguna terdapat Logo Produk terichip yang diikuti menu horizontal di sebelah kanannya. Di bawah menu terdapat Gambar utama beserta judul gambar dan informasi tentang gambar tersebut. Pada bagian kiri bawah halaman terdapat informasi tentang Terichip dan Alamat serta nomor kontak yang bisa dihubungi. Sedangkan pada bagian kanan bawah, terdapat pula menu-menu pilihan termasuk menu untuk masuk atau mendaftar sebagai donator.

Desain antarmuka donatur dibuat sesuai kebutuhan donatur yang ingin berdonasi. Halaman ini dapat diakses setelah pengguna umum (user) mendaftara sebagai Donatur dan melakukan login pada pilihan menu yang tersedi di halaman user.

Menu utama yang ada pada halaman donatur meliputi profil donatur yaitu informasi data diri dan juga menu untuk mendonasikan dana melalui transfer rekening. Desain antarmuka halaman donatur ditunjukkan pada gambar 2.

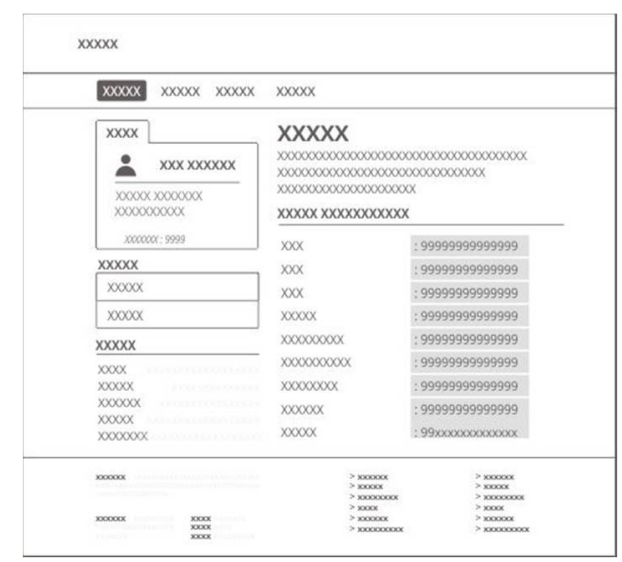

Gambar 2. Desain antarmuka donatur

Pada sisi kiri atas halaman donatur tertera profil donatur yang memuat informasi data diri. 
Sedangkan pada sisi kanan halaman tertera daftar nama Bank beserta nomor rekening yang dapat digunakan untuk mengirimkan donasi.

Pada sisi bawah halaman terdapat informasi tentang Terichip dan Alamat serta nomor kontak yang bisa dihubungi. Tampilan informasi pada bagian ini relatif sama dengan yang terdapat pada halaman pengguna (user).

Pada halaman admin, informasi yang ditampilkan tidak hanya dapat dilihat tetapi juga dapat dikelola. Desain antarmuka untuk halaman admin ditunjukkan pada gambar 3 .

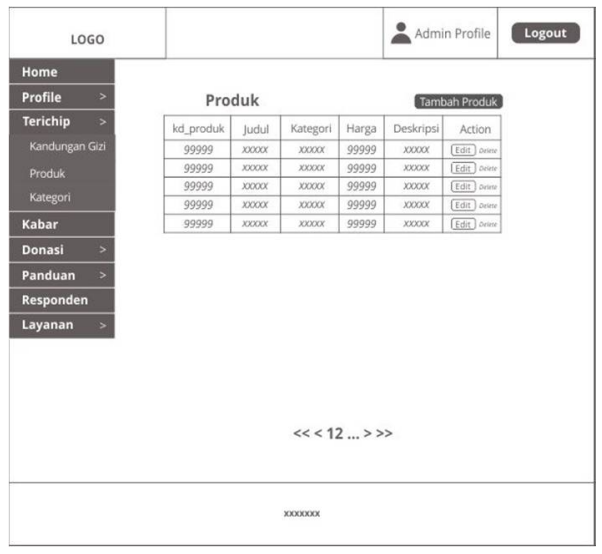

Gambar 3. Desain antarmuka Admin

Halaman admin memiliki perbedaan dengan halaman pengguna dan donatur. Selain dari sisi fungsi akses yang berbeda, peletakkan menu dan tampilan informasi utama juga sangat berbeda.

Pada bagian atas terdapat Logo, Profil admin dan menun untuk keluar (log out).

Menu utama admin terletak di sisi kiri halaman menggunakan menu vertical. Informasi utama terletak di sisi kanan tengah, lengkap dengan fasilitas menu untuk mengelola informasi yaitu Tambah, Ubah (edit) dan Hapus (delete). Bagian bawah dari halaman admin terdapat footer yang memuat informasi singkat yang berbeda dengan tampilan footer pada halaman pengguna maupun donatur.

Setelah Desain antarmuka dibuat, langkah selanjutnya adalah membuat rancangan basis data menggunakan ERD dan LRS. Dari kedua rancangan awal ini dapat dilihat relasi antar entitas lengkap dengan atribut-atributnya. Relasi inilah yang kemudian digunakan untuk merancang spesifikasi file basis data.

Rancangan ERD dan LRS berturut-turut ditunjukkan pada gambar 4 dan 5 .

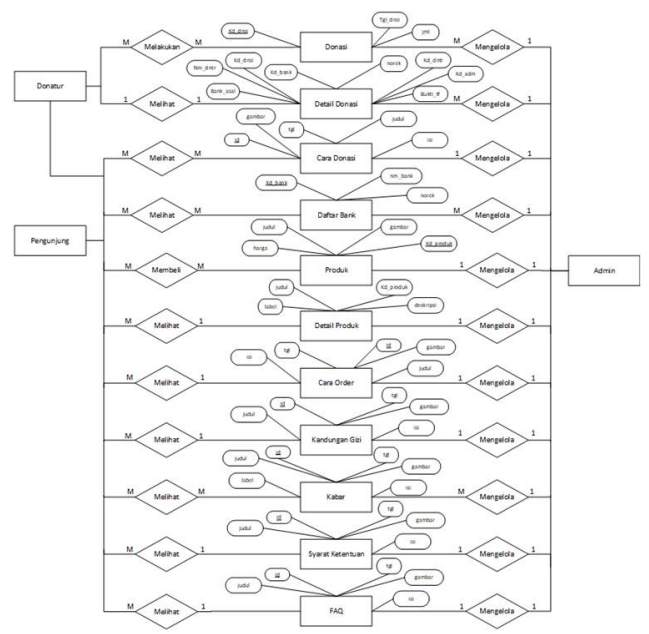

Gambar 4. Entity Relationship Diagram
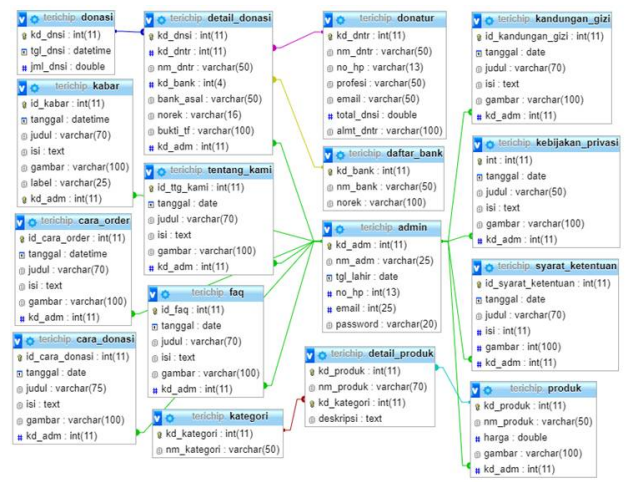

\section{Gambar 5. Logical Record Structure}

ERD dan LRS pada dasarnya sama-sama menunjukkan relasi antar entitas atau tabel data yang disimpan dalam basis data. Setiap tabel dihubungkan menggunakan Kunci Primer (primary key) yang bersifat unik. Pada ERD kunci primer ditunjukkan pada atribut yang digaris-bawahi sedangkan pada LRS ditunjukkan dengan simbol bintang $\left(^{*}\right)$ atau kunci. Kunci primer ini terhubung dengan kunci primer pada tabel lain yang disebut sebagai kunci asing (foreign key). Kunci asing ditunjukkan dengan tanda dua bintang $\left(^{(*}\right)$ atau tanda pagar (\#).

Pada ERD dan LRS yang ditunjukkan pada gambar 4 dan 5 dapat dilihat relasi antar menu yang ada di sistem dengan setiap pengguna, baik itu user, donatur maupun admin. Pembeda utama dari ketiganya adalah hak akses ataupun proses yang dikenakan. Dalam bentuk geometri laying-layang ditunjukkan bahwa admin memiliki kewenangan untuk mengelola setiap tabel basis data, sedangkan user dan donatur hanya dapat melihat tabel-tabel data tersebut.

Perancangan yang perlu dilakukan selanjutnya adalah menentukan spesifikasi file 
dari setiap tabel basis data. Sebagai contoh, untuk file Daftar Bank dirancang spesifikasi file seperti yang ditunjukkan pada tabel 2 .

Tabel 2. Spesifikasi file Daftar bank

\begin{tabular}{|c|c|c|c|c|c|}
\hline $\begin{array}{c}\text { N } \\
0\end{array}$ & Elemen Data & $\begin{array}{c}\text { Nama } \\
\text { Field }\end{array}$ & Tipe & $\begin{array}{c}\text { Valu } \\
\text { es }\end{array}$ & $\begin{array}{c}\text { Ke } \\
\mathrm{t}\end{array}$ \\
\hline 1 & Kd Bank & kd_bank & int & 4 & $\begin{array}{c}P \\
K\end{array}$ \\
\hline 2 & Nama Bank & nm_bank & $\begin{array}{c}\text { Varch } \\
\text { ar }\end{array}$ & 50 & \\
\hline 3 & No Rekening & Norek & int & 16 & \\
\hline
\end{tabular}

Kunci Utama (PK) pada file Daftar Bank adalah Kode bank yang diberi Nama Field kd_bank. Hal ini dilakukan untuk mengurangi resiko kesamaan nama bank ataupun no rekening. Tipe data yang digunakan untuk kode bank adalah integer yang memuat 4 digit angka (bilangan bulat). Sedangkan untuk nama bank, karena nantinya akan digunakan untuk menyimpan karakter maupun angka dan simbol, maka menggunakan tipe data Var Char sebesar 50 karakter.

\section{Pengkodean (Coding)}

Pengkodean dilakukan menggunakan tools program yaitu Adobe Dreamweaver. Fungsi utama pengkodean adalah menghubungkan desain perangkat lunak agar dapat berfungsi seperti yang diharapkan.

Desain antarmuka diimplementasikan dengan cara dihubungkan ke basis data sesuai alur navigasi. Pada Gambar 6 dan 7 secara berturut-turut ditampilkan struktur navigasi untuk Donatur dan Admin.

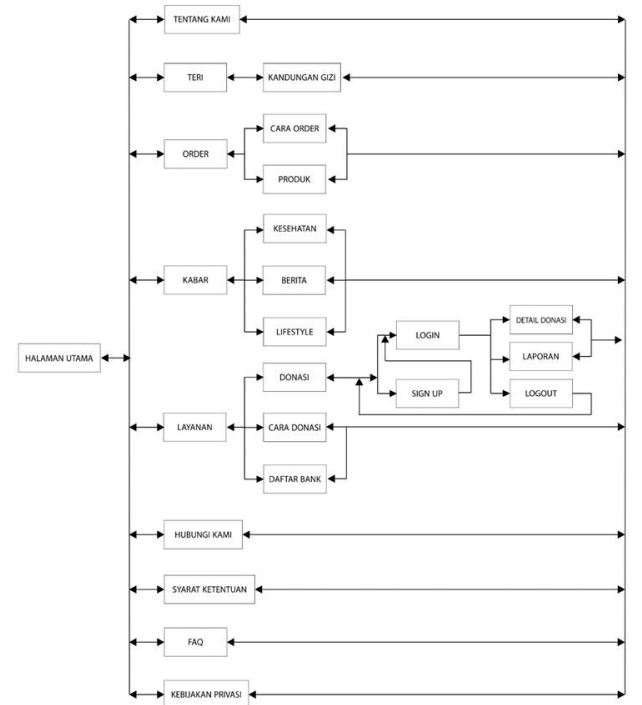

Gambar 6. Struktur Navigasi Pengguna

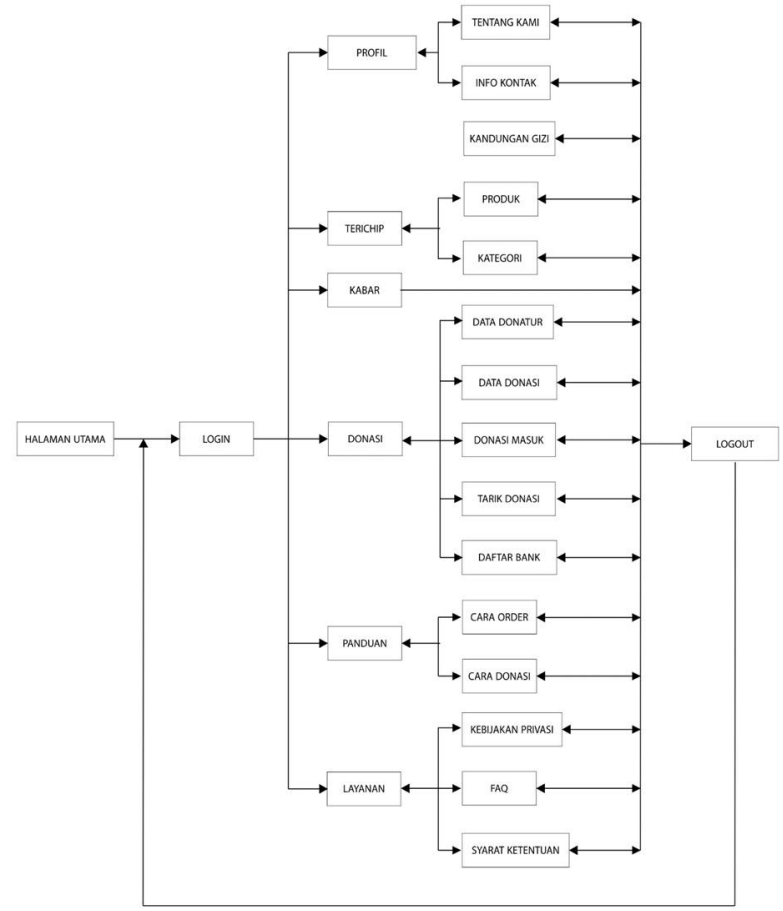

Gambar 7. Struktur Navigasi Admin

\section{Pengujian (Testing)}

Tahap pengujian dilakukan setelah semua proses implementasi rancangan selesai. Pengujian dilakukan dengan memberikan masukan di setiap halaman dan form isian yang tersedia. Masukan bisa berupa karakter, angka maupun dengan menekan tombol pilihan menu. Kesesuaian alur navigasi dan hasil yang diproses menunjukkan keberhasilan perancangan sistem.

Berdasarkan pengujian yang dilakukan, sistem berbasis website ini telah berjalan sesuai dengan perancangan dan dapat menghasilkan keluaran seperti yang diharapkan. Sebagai contoh, pada halaman login donatur maupun admin. Hanya jika Username dan Password yang dimasukkan benar, maka tampilan akan beralih ke halaman utama donatur maupun admin.

\section{Penutup}

Berdasarkan hasil pengujian dan penelitian dapat disimpulkan bahwa:

1. Website ini dapat dijadikan sebagai media promosi dalam meningkatkan penjualan produk terichip via online.

2. Website ini dapat menjadi sarana edukasi akan pentingnya asupan kalsium bagi ibu hamil dan menyusui.

3. Mempermudah konsumen mendapatkan produk terichip secara online.

4. Membuka peluang bagi donatur untuk ikut berkontribusi dalam aksi sosial. 


\section{Daftar Pustaka}

Destiana, Henny. (2014). Sistem Informasi Penjualan Barang Berbasis Web pada PT. Catur Daya Persada Jakarta. Vol. XVI number 2, September 2014. Diambil dari: http:// ejournal. bsi. ac.id/ejurnal/index.php/ paradigma/ article/view/775

Istiono, Wirawan, Hijrah, dan Sutarya. (2016). Pengembangan Sistem Aplikasi Penilaian dengan Pendekatan MVC dan Menggunakan Bahasa PHP dengan Framework Codeigniter dan Database MYSQL pada Pahoa College Indonesia. Vol. 5 number 1, September 2016. Diambil dari https:// media.neliti. com/media/publications /93757-ID-pengembangan-sistemaplikasi -penilaian-d.pdf

Nugrahani, Gardinia.(2014). Pengaruh Substitusi Ikan Teri Nasi (Stolephorus sp.) Terhadap Kandungan Protein, Kalsium dan Mutu Organoleptik Omelet. Semarang : Program Studi IImu Gizi Fakultas Kedokteran Universitas Diponegoro Semarang.

Pribadi, Catur Agung.(2016). Perancangan Website Kampanye Kelas Inspirasi Bangkalan. Vol. 04 number 03, 2016.
Diambil dari : http://jurnalmahasiswa. unesa.ac.id/index.php/va/article/view/1 $7720 / 16133$

Purnasari, Galih, Dodik Briawan, dan Cesilia Meti Dwiriani.(2016). Kepatuhan Konsumsi Suplemen Kalsium Serta Hubungannya Dengan Tingkat Kecukupan Kalsium Pada Ibu Hamil Di Kabupaten Jember. Vol. 7 number 2, 2016. Diambil dari : https:// media.neliti.com/media/ publications/ 107999 - ID - kepatuhan - konsumsi suplemen - kalsium-sert.pdf.

Purnasari, Galih, Dodik Briawan, dan Cesilla Meti Dwiriani. (2016) . Asupan Kalsium dan Tingkat Kecukupan Kalsium Pada Ibu Hamil di Kabupaten Jember. Vol. 12 number 4, Desember 2016. Diambil dari https://media.neliti.com/media/publicati ons/212637-asupan-kalsium-dantingkat-kecukupan-kal.pdf

Supriyanta, dan Eunike Nova Dwi Floren Rindani Nussy. (2016) . Perancangan Website Sebagai Media Informasi Panti Asuhan Batu Penjuru Kulon Progo. Vol. 8 number 2, 2016. Diambil dari http://ejurnal.net/portal /index.php/speed/article/view/517/46 